\title{
Patterns of microbial diversity along a salinity gradient in the Guerrero Negro solar saltern, Baja CA Sur, Mexico
}

\author{
Jesse G. Dillon *, Mark Carlin, Abraham Gutierrez, Vivian Nguyen and Nathan McLain
}

Department of Biological Sciences, California State University, Long Beach, CA, USA

\section{Edited by:}

R. Thane Papke, University of

Connecticut, USA

Reviewed by:

R. Thane Papke, University of Connecticut, USA

Lejla Pašić, University of Ljubljana,

Slovenia

*Correspondence:

Jesse G. Dillon, Department of

Biological Sciences, California State University, 1250 Bellflower Blvd.,

Long Beach, CA 90840, USA

e-mail: jesse.dillon@csulb.edu
The goal of this study was to use environmental sequencing of 16S rRNA and bop genes to compare the diversity of planktonic bacteria and archaea across ponds with increasing salinity in the Exportadora de Sal (ESSA) evaporative saltern in Guerrero Negro, Baja CA S., Mexico. We hypothesized that diverse communities of heterotrophic bacteria and archaea would be found in the ESSA ponds, but that bacterial diversity would decrease relative to archaea at the highest salinities. Archaeal 16S rRNA diversity was higher in Ponds 11 and 12 (370 and $380 \mathrm{~g} \mathrm{I}^{-1}$ total salts, respectively) compared to Pond 9 (180 g I-1 total salts). Both Pond 11 and 12 communities had high representation (47 and $45 \%$ of clones, respectively) by Haloquadratum walsbyi-like (99\% similarity) lineages. The archaeal community in Pond 9 was dominated (79\%) by a single uncultured phylotype with $99 \%$ similarity to sequences recovered from the Sfax saltern in Tunisia. This pattern was mirrored in bop gene diversity with greater numbers of highly supported phylotypes including many Haloquadratum-like sequences from the two highest salinity ponds. In Pond 9, most bop sequences, were not closely related to sequences in databases. Bacterial 16S rRNA diversity was higher than archaeal in both Pond 9 and Pond 12 samples, but not Pond 11, where a non-Salinibacter lineage within the Bacteroidetes $>98 \%$ similar to environmental clones recovered from Lake Tuz in Turkey and a saltern in Chula Vista, CA was most abundant (69\% of community). This OTU was also the most abundant in Pond 12 , but only represented $14 \%$ of clones in the more diverse pond. The most abundant OTU in Pond 9 (33\% of community) was $99 \%$ similar to an uncultured gammaproteobacterial clone from the Salton Sea. Results suggest that the communities of saltern bacteria and archaea vary even in ponds with similar salinity and further investigation into the ecology of diverse, uncultured halophile communities is warranted.

Keywords: halophile, gradient, saltern, 16S rRNA gene, bop gene, haloarchaea

\section{INTRODUCTION}

Some of the best examples of chemical gradients are found in solar salterns around the world (Anton et al., 2000; Litchfield et al., 2001; Baati et al., 2008; Oren, 2008; Manikandan et al., 2009; Oh et al., 2010). Like most hypersaline habitats, these evaporation ponds typically contain abundant microbial populations including members of all three domains of life (Javor, 1989). Traditional cultivation studies as well as molecular sequencing and FISH studies in salterns have revealed diverse communities dominated by phototrophs like Dunaliella as well as aerobic heterotrophic prokaryotes (Anton et al., 1999; Benlloch et al., 2001; Pašić et al., 2005; Maturrano et al., 2006; Papke et al., 2007; Baati et al., 2008). However, biogeographic differences in the specific communities found in salterns have been observed, perhaps due to dispersal limitation (Oren and Rodriguez-Valera, 2001; Zhaxybayeva et al., 2013).

Variation in prokaryotic communities along salinity gradients has also been reported as studies have found that microbial species richness decreases with increasing salinity, often resulting in a few dominant phylotypes found in highest salinity ponds (Casamayor et al., 2000; Benlloch et al., 2002; Baati et al., 2008).
In many salterns the highest salinities are dominated by haloarchaea such as Haloquadratum and Halorubrum (Anton et al., 1999; Burns et al., 2004; Maturrano et al., 2006; Oh et al., 2010) as well as having significant proportions (up to 15-27\%) of extremely halophilic members of Salinibacter (Anton et al., 2000; Oren, 2002; Øvreås et al., 2003; Anton et al., 2008). However, in other salterns, Haloquadratum (Pašić et al., 2005) or Salinibacter (Maturrano et al., 2006) are absent or rare.

The saltern Exportadora de Sal (ESSA) in Guerrero Negro, Baja CA S., Mexico covers an area over $300 \mathrm{~km}^{2}$ and is the world's largest producer of evaporative salt. Salt water is pumped yearround from the modestly hypersaline Ojo de Liebre lagoon and than slowly pumped through a series of large (many $\left.>1 \mathrm{~km}^{2}\right)$, shallow ( $\sim \mathrm{m}$ deep), interconnected ponds. The ponds display a gradient of chemical make-up as salts precipitate (e.g., gypsum) as the water moves up the evaporation scale for over a year (Javor, 1983). As with many salterns, environmental conditions are quite stable over time. Nutrient levels are relatively low at the ESSA saltern and it has been classified as oligotrophic (Javor, 1983, 1989). The ESSA saltern has been intensively studied. However, most of the research on the diversity of gene sequences of 
microbes in this system has focused either on the well-developed, benthic microbial mats found at moderate salinities $(\sim 70-100 \mathrm{~g}$ $1^{-1}$ ) (Nübel et al., 2001; Ley et al., 2006; Feazel et al., 2008; Kunin et al., 2008; Dillon et al., 2009b; Robertson et al., 2009) or within evaporites (Sahl et al., 2008). Few studies have been performed in the ESSA ponds at higher salinities $\left(>150-160 \mathrm{~g} \mathrm{l}^{-1}\right)$, where planktonic communities dominate (Javor and Castenholz, 1981) and these were primarily cultivation-based (Javor, 1984; Sabet et al., 2009). This study represents the first use of cultureindependent, molecular techniques to examine the diversity of planktonic microbes in the ESSA saltern at the highest salinities where benthic microbial mats are not found. Based on the prior cultivation work, we hypothesized that diverse communities of both halophilic bacteria and archaea would be found in the ESSA ponds, but that bacterial community diversity would decrease in comparison with archaea at the highest salinities.

\section{METHODS AND MATERIALS WATER SAMPLE COLLECTION AND ANALYSIS}

In conjunction with a broader study aimed at cultivation of halophiles (Sabet et al., 2009), water samples were collected in February, 2006, from three ponds along a salinity gradient at the ESSA saltworks, Guerrero Negro, Baja California Sur, Mexico. Replicate $50 \mathrm{ml}$ water samples $(n=3-5)$ were collected via nearshore surface grabs in evaporative ponds (Ponds 9 and 11) and in a crystallizer pond (Pond 12). Samples were frozen in liquid nitrogen for transport back to CSU Long Beach and stored at $-80^{\circ} \mathrm{C}$ prior to analysis. Pond 9 bottom was covered with gypsum precipitate, while Pond 12 contained halite with Pond 11 showing a soft sediment bottom with evidence of both gypsum and halite precipitates. Salinity (total salts) of each water source was measured using a refractometer and when salinities were off scale (i.e., $>280 \mathrm{~g} \mathrm{l}^{-1}$ ) by dilution prior to reading. Water temperature was measured for each pond using a handheld probe (Russell RL060P, Thermo Electron Corp., Beverly, MA, USA). Water samples $(n=1)$ were filtered through a $0.2 \mu \mathrm{m}$ filter, diluted, and analyzed for major cation content using inductivelycoupled plasma mass spectrometry (ICP-MS) at the Institute for Integrated Research in Materials, Environments, and Society (IIRMES) on the CSULB campus and anions via ion chromatography (882 Compact IC plus, Metrohm, Riverview, FL, USA) using the EPA 300.0 method at Physis Environmental Laboratories (Anaheim, CA).

\section{DNA EXTRACTION}

The $50 \mathrm{ml}$ water samples were thawed and pre-filtered through a $10 \mu \mathrm{m}$ dia. pore size nylon membrane filters (GE Osmonics, Minnetonka, MN) to remove large particles and algae. The water was re-filtered through a $0.22 \mu \mathrm{m}$ polysulfone membrane (GE Osmonics) to collect the bacterial and archaeal cell fraction. Nucleic acids were extracted from the filter using a modified protocol of Benlloch et al. (2001). Filters were cut into pieces, washed with $2 \mathrm{ml}$ of sterile nanopure water, vortexed, and the supernatant treated with SDS ( $1 \% \mathrm{w} / \mathrm{v})$ and proteinase $\mathrm{K}(0.5 \mathrm{mg}$ $\mathrm{ml}^{-1}$ ) and the samples incubated at $55^{\circ} \mathrm{C}$ for $2 \mathrm{~h}$, then boiled for 2 min. Nucleic acids were extracted twice with 1 volume of phenol/chloroform/isoamyl alcohol (IAA) (50:49:1), centrifuged at $3300 \times \mathrm{g}$ for $20 \mathrm{~min}$, and extracted again with an equal volume of chloroform:IAA (49:1) and centrifuged for an additional $5 \mathrm{~min}$. The aqueous supernatants were precipitated in 2 volumes of $100 \%$ ethanol and centrifuged at $3220 \times \mathrm{g}$ for $20 \mathrm{~min}$ at $4^{\circ} \mathrm{C}$. The supernatant was decanted and the tube was allowed to dry. The pellet was resuspended in $100 \mu \mathrm{L}$ sterile nanopure water, incubated at $55^{\circ} \mathrm{C}$ for $30 \mathrm{~min}$ and stored at $-20^{\circ} \mathrm{C}$.

\section{PCR, CLONING, AND SEOUENCING}

PCR amplifications of 16S rRNA were performed using purified nucleic acid and bacterial 16S rRNA primers GM3f (5'AGAGTTTGATCMTGGC) and GM4r (5'-TACCTTGTTACGAC TT) (Muyzer et al., 1995) and archaeal 16S rRNA primers arch21f (TTCCGGTTGATCCYGCCGGA) (Delong, 1992) with either the archaea-specific 958r (YCCGGCGTTGAMTCCAATT) (Delong, 1992) or the universal 1392r reverse primer (Stahl et al., 1988). Amplifications of bacteriorhodopsin (bop) genes used the bop401F (GACTGGTTGTTYACVACGCC) and bop795R (AAG CCGAAGCCGAYCTTBGC) primers (Papke et al., 2007). The $20 \mu \mathrm{L}$ reaction mixtures contained $1 \times$ PCR buffer (Invitrogen, Carlsbad, CA), $0.2 \mathrm{mM}$ each dNTP (Promega, Madison, WI), 10 pmol each primer (Operon, Huntsville, AL), 1 U Platinum Taq polymerase (Invitrogen), and 50-100 ng of purified nucleic acids. For most samples, $1 \mu \mathrm{l}$ of bovine serum albumin $(0.4 \% \mathrm{w} / \mathrm{v})$ was added to reaction mixtures to facilitate amplification. Reaction conditions were as follows: initial denaturation $\left(94^{\circ} \mathrm{C}\right.$ for $\left.5 \mathrm{~min}\right)$ followed by 30 cycles of denaturation $\left(94^{\circ} \mathrm{C}\right.$ for $\left.30 \mathrm{~s}\right)$, annealing $\left(53^{\circ} \mathrm{C}\right.$ for $\left.30 \mathrm{~s}\right)$, and extension $\left(72^{\circ} \mathrm{C}\right.$ for $\left.90 \mathrm{~s}\right)$ and a final extension $\left(72^{\circ} \mathrm{C}\right.$ for $10 \mathrm{~min}$ ) using a mastercycler (Eppendorf, Hauppauge, $\mathrm{NY}$ ). The resulting amplicons were ligated into pCR4 TOPO vector with the $\mathrm{TOPO}^{\circledR}$ Cloning $\mathrm{PCR}$ Cloning Kit (Invitrogen, Carlsbad, CA) and transformed into One Shot ${ }^{\circledR}$ TOP10 chemically competent $E$. coli cells according to the manufacturer's instructions. Transformants were plated on LB plates with $100 \mu \mathrm{g}$ $\mathrm{L}^{-1}$ ampicillin. For each sample, colonies were picked with a sterile toothpick and grown up in $75 \mu \mathrm{L}$ of $\mathrm{LB}+$ ampicillin broth in 96-well plates, diluted to a final concentration of $15 \%(\mathrm{w} / \mathrm{v})$ with sterile glycerol, and stored at $-80^{\circ} \mathrm{C}$. For all clones, cells were grown in $2 \mathrm{ml}$ of $\mathrm{LB}+$ ampicillin broth at $37^{\circ} \mathrm{C}$ overnight and plasmid minipreps performed using the GenCatch plasmid DNA purification kit (Epoch Biolabs, Sugar Land, TX). Plasmids were sequenced with M13forward and reverse primers by a commercial sequencing facility (University of WA High Throughput Genomic Center, Seattle, WA).

\section{PHYLOGENETIC AND STATISTICAL ANALYSES}

For 16S rRNA a total of 296 archaeal sequences and 254 bacterial sequences were obtained from 1-2 clone libraries for each pond separately for each gene. Chimera detection of sequences was performed using Mallard software analysis (Ashelford et al., 2006) and Pintail (Ashelford et al., 2005). Non-chimeric 16S rRNA sequences were aligned using the SINA aligner on the SILVA website (Pruesse et al., 2007) and imported into ARB software and manually refined with reference to nearest neighbor taxa from the v. 102 database (Ludwig et al., 2004). A total of 167 high quality 
bop sequences were derived from a total of 288 clones generated via a single 96-clone library from each pond. These sequences were initially aligned to all available gene sequences in the NCBI website using Clustal X (Larkin et al., 2007), and then imported into a custom-created ARB database. Custom lane masks of aligned sequences were created excluding hypervariable regions (16S rRNA genes) and ambiguous nucleotide positions. This resulted in the export of $874 \mathrm{nt}$ (archaeal 16S rRNA) and $1033 \mathrm{nt}$ (bacterial 16S rRNA) and $312 \mathrm{nt}$ (bop). Maximum Likelihood trees were constructed using the Blackbox RaxML tool on CIPRES Science Gateway v. 7.2 (Miller et al., 2010) with 750 bootstrap pseudoreplications or fewer if stopped using the automated MRE bootstopping criterion (e.g., 250, bacterial 16S rRNA). Where full-length sequences were not obtained, partial sequences were added to the $16 \mathrm{~S}$ rRNA trees using the parsimony tool in ARB.

Additional statistical analyses of the three ponds' clone library sequences were performed using distance matrices generated in ARB (Ludwig et al., 2004). These datasets differed from those used for phylogenetic analyses in that redundant sequences were included, and new custom filters were made for archaeal (304 nt), bacterial (412 nt), and bop (356 nt) sequences. Exported similarity matrices were used to cluster sequences into OTU by pair-wise sequence identity with the average neighbor algorithm at a evolutionary distance of 0.00 (actually represents $<0.005$ ), $0.01,0.03$, and 0.05 (Schloss et al., 2009) corresponding to the $100,99,97$, and 95\% similarity cut-offs, respectively. Rarefaction curves were generated using a resampling without replacement approach. Estimations of alpha diversity metrics (Chao1, ACE Richness, Shannon's Index, Simpson's Index) were also performed using MOTHUR. Richness and diversity estimates were calculated on random subsamples set to the size of the smallest library to alleviate biases by sample size (Youssef and Elshahed, 2008; Gihring et al., 2012). Percent coverage of the libraries, which determines the probability that all genotypes present in a given set of samples were recovered at least once, was calculated as follows: $\left[1-\left(n_{i} / N\right)\right] * 100$ where $n_{i}$ is the number of unique OTU and $\mathrm{N}$ is the total number of clones sampled in the library (Good, 1953). The statistical comparison of community structure among the three ponds' clone libraries was tested using $\int$-Libshuff and analysis of molecular variance (AMOVA) as implemented in Mothur software (Schloss et al., 2009). AMOVA tests whether the genetic diversity within communities is significantly different from their pooled genetic diversity (Schloss, 2008). $\int$-Libshuff uses the integral form of Cramér-von Misestype statistic as described in Schloss et al. (2009). To account for multiple comparisons among the three libraries (i.e., Ponds 9, 11, 12), Bonferroni corrections for $P$-values were used to determine significance.

Physicochemical data were analyzed using a Principal Components Analysis (PCA) using Primer software v. 6.1.11 (Primer-E Ltd., Plymouth, UK).

\section{NUCLEOTIDE SEOUENCE ACCESSION NUMBERS}

Sequences were deposited in GenBank and were assigned the accession numbers KF234269-KF234397, KF814118-KF814651, and KF870833-KF870836.

\section{RESULTS}

\section{PHYSICOCHEMICAL CHARACTERIZATION OF PONDS}

Total salinity increased across the three ponds with Pond 9 at $180 \mathrm{~g} \mathrm{l}^{-1}$ and the other two ponds being more similar at 370 and $380 \mathrm{~g} \mathrm{l}^{-1}$ salinity. PCA based on variation in physicochemical variables confirmed that Pond 11 and 12 were more similar to each other than to Pond 9 with the majority of the variation (98.4\%) observed along the primary axis, which can be explained by variation in chemical species, but not temperature (Figure 1). Most major cations and anions increased in concentrations with the exceptions of $\mathrm{Ca}^{2+}$ (Table 1). This is reflected by the difference in directionality of the eigenvector for calcium compared to the other ions. The drop in calcium concentration in Pond 11 and 12 is likely due to precipitation of gypsum $\left(\mathrm{CaSO}_{4}\right)$, which begins in Pond 9. Somewhat surprisingly, sulfate concentrations did not decline in parallel with calcium concentration. The slight drop in sodium and chloride ions in Pond 12 water compared to Pond 11 is likely due to the precipitation of halite $(\mathrm{NaCl})$ at these elevated salinities; halite deposition was apparent in Pond 12.

\section{ARCHAEAL 16S rRNA SEQUENCE DIVERSITY ACROSS ESSA SALTERN PONDS}

Archaeal 16S rRNA sequence diversity included members of genera previously cultured from the ESSA saltern including

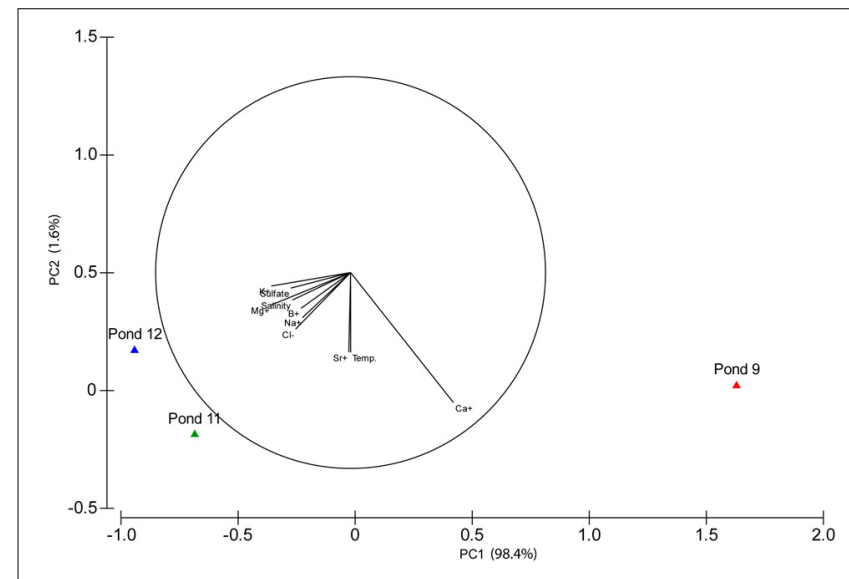

FIGURE 1 | Principal Components Analysis (PCA) biplot. Vectors show the direction of maximum change for variables.

Table 1 | Physicochemical parameters in evaporation ponds.

\begin{tabular}{llll}
\hline Ponds & $\mathbf{9}$ & $\mathbf{1 1}$ & $\mathbf{1 2}$ \\
\hline Temp. $\left({ }^{\circ} \mathrm{C}\right)$ & 17.3 & 18.9 & 16.2 \\
Salinity $\left(\mathrm{g} \mathrm{I}^{-1}\right)$ & 180 & 370 & 380 \\
$\mathrm{Cl}^{-}\left(\mathrm{mg} \mathrm{I}^{-1}\right)$ & 85,460 & 174,160 & 168,880 \\
$\mathrm{SO}_{4}^{2-}\left(\mathrm{mg} \mathrm{I}^{-1}\right)$ & 11,256 & 23,234 & 24,434 \\
$\mathrm{Na}^{+}\left(\mathrm{mg} \mathrm{I}^{-1}\right)$ & 46,460 & 86,250 & 84,650 \\
$\mathrm{Mg}^{+}\left(\mathrm{mg} \mathrm{l}^{-1}\right)$ & 6130 & 16,390 & 17,160 \\
$\mathrm{~K}^{+}\left(\mathrm{mg} \mathrm{l}^{-1}\right)$ & 1982 & 5155 & 5585 \\
$\mathrm{Ca}^{+}\left(\mathrm{mg} \mathrm{I}^{-1}\right)$ & 1204 & 407 & 280 \\
$\mathrm{~B}^{+}\left(\mathrm{mg} \mathrm{I}^{-1}\right)$ & 14 & 27 & 27 \\
$\mathrm{Sr}^{+}\left(\mathrm{mg} \mathrm{I}^{-1}\right)$ & 26 & 29 & 25
\end{tabular}


numerous Halorubrum-like sequences (OTU 14-19, 90-99\% similarity to cultured species) obtained from all three ponds at clonal abundances of $1-11 \%$ of the community (Figure 2 ). We also recovered one Haloarcula-like clone (98\% similarity) from Pond 12. Pond 11 and 12 clone libraries were dominated (62 and $70 \%$, respectively) by a diverse assemblage of closely related Haloquadratum-like sequences (OTU 1-6). This was especially true of a single lineage $99 \%$ similar to the type species $H$. walsbyi (OTU 1, 47 and 45\% of Ponds 11 and 12 community, respectively). The other five, less abundant OTU in this group ranged from $1-12 \%$ of community and were $92-99 \%$ similar to $H$. walsbyi. Some of these lineages were highly similar ( $98 \geq 99 \%)$ to environmental sequences obtained in Australian crystallizer ponds (Oh et al., 2010) and the Santa Pola saltern in Spain (Zhaxybayeva et al., 2013) (Figure 2). Sequences related to Halorhabdus utahense (OTU 10) represented $2-3 \%$ of clones in Pond 11 (98\% similar). Additionally, lineages related to other uncultured haloarchaeal lineages with no known cultured representative within the family Halobacteriaceae were observed at all sites.

In Pond 9, a Halorubrum-like lineage (OTU 18, 1\% of community) and singletons $(\sim 6 \%$ total) were nearly identical (>99.5\% similar) to environmental sequences from the Santa Pola saltern (Zhaxybayeva et al., 2013). Aside for these, Pond 9 clone sequences were exclusively related to uncultured haloarchaeal lineages. One lineage (OTU 12, 12\% of the community) was $>97 \%$ similar to an environmental clone from a Chinese saltern. However, the preponderance (79\% of community) was a single, highly redundant lineage most closely related (99\% similarity) to sequences recovered from the Sfax saltern in Tunisia (Trigui et al., 2011) (OTU 7, Figure 2). This redundancy of phylotypes in Pond 9 was reflected in much lower species richness and diversity metrics in this community compared with the communities in the two salt-saturated ponds (Table 2) and a flatter rarefaction curve in the Pond 9 sample (Figure 3A) at most similarity levels. We analyzed the alpha diversity results at 4 different OTU cut-offs: $0,1,3$, and 5\% evolutionary distance levels among sequences. Regardless of cut-off used, the number of OTUs calculated and the Shannon's and Simpson's diversity (shown as $1 / D=$ Dominance) were always lower for Pond 9 than the other two ponds, and the Pond 9 rarefaction curves were always lower than Pond 11 and 12 at each cut-off (Figure 3A). However, the richness estimates (Chaol and $\mathrm{ACE}$ ) were much higher at the $0 \%$ cut-off than at other similarity levels within Pond 9, and both the estimates were even higher than Pond 11 at this level. These results suggest that there were a number of unique, but highly similar $(<1 \%)$ OTUs in Pond 9, many in the abundant OTU 7 (data not shown). Significant community overlap between the archaeal $16 \mathrm{~S}$ rRNA communities in Ponds 11 and 12 was confirmed with the $\int$-LIBSHUFF and AMOVA comparisons both of which showed no significant difference between the two libraries (Table 3), but highly significant differences when those libraries were compared with the Pond 9 library. This was also reflected in the Venn diagram showing overlap of OTUs among pond communities at the 4 levels of similarity (Figure 3D). High degrees of overlap were observed between Ponds 11 and 12 at all similarity levels, but less overlap (2 OTUs) were observed between Ponds 9 and 11 and no overlap was observed between Ponds 9 and 12 until the 5\% evolutionary distance threshold was employed. The overlapping OTUs between Ponds 9 and 11 were the Halorubrum-like lineage (OTU 18, 99\% similarity) and the uncultured lineage recovered from a Chinese saltern (OTU12, 97\% similarity).

\section{BACTERIORHODOPSIN GENE DIVERSITY}

We successfully created an alignment and ARB database of bop sequences from this study and those downloaded from the Genbank database and created a phylogenetic tree (Figure 4). Overall, similar patterns of community shifts across the ponds to the archaeal rRNA library were observed when bop nucleotide sequences were analyzed. Many environmental clones were recovered from Ponds 11 and 12 (58 and 77\% of community, respectively) that had $>90 \%$ bootstrap support for clustering with $H$. walsbyi on the tree (Figure 4). These varied in similarity from 98\% (OTU 4), 95\% (OTUs 5-6), 90\% (OTU 3) to 75\% (OTUs $1-2)$ to the $H$. walsbyi bop gene sequence. Sequences in the latter group were $96-100 \%$ similar to environmental clones reported in one of the few published environmental bop surveys from the Santa Pola saltern (Papke et al., 2003). Only a single sequence, $88 \%$ similar to a cultured Halorubrum from the same study, was obtained from Pond 11 and no Haloarcula were found in the environmental bop library. This was unexpected since we detected both these groups with 16S rRNA genes in Pond 12 and we have successfully cultivated members of these genera from the ESSA ponds (see bolded culture bop sequences in Figure 4). Additionally, one Pond 11 lineage (OTU 10, Figure 4) was closely related ( $\sim 96 \%$ similar) to environmental clones from both Santa Pola and a saltern in Chiku, Taiwan (Lin et al., unpublished). However, none of the Pond 9 clones were closely related to any sequences in Genbank (Figure 4). One cluster of closely related OTUs (7-9, 95-98\% similar to each other, 71\% similar to $H$. walsbyi) represented $44 \%$ of clones in Pond 9 and was only found in that location. Only one well-supported cluster (100\% bootstrap) of sequences was found in both Ponds 9 and 11 (OTUs 12-13 plus singletons). This phylogroup comprised $48 \%$ of the community in Pond 9 and 25\% in Pond 11, and again had no close cultured relative (70-71\% similar to Natronococcus and Halobiforma bop sequences). As with the archaeal $16 \mathrm{~S}$ rRNA data, higher species richness and diversity was found in Ponds 11 and 12 compared to Pond 9 (Table 2) at most OTU cutoffs, reflected in higher OTU redundancy in the Pond 9 rarefaction curves (Figure 3B). Once again the exception was the $0 \%$ evolutionary distance cutoff, where very high richness estimates were observed for Pond 9 resulting in the steepest rarefaction curve of all (Figure 3B). For bop gene analyses, the OTU number and diversity metrics in Pond 9 were even higher than the other ponds at the $0 \%$ level, while they were the lowest for all measures with this sample at the 1 and 3\% OTU distance level (Table 2). As with archaeal 16S rRNA genes, more overlap was found between Ponds 11 and 12 at all similarity levels with only 2 OTUs (uncultured OTU 12-13) shared between Pond 9 and 11 and none between Ponds 9 and 12 (Figure 3E).

\section{BACTERIAL DIVERSITY PATTERNS}

Compared with the archaeal 16S rRNA libraries, even greater diversity of bacterial 16S rRNA phylotypes was recovered 


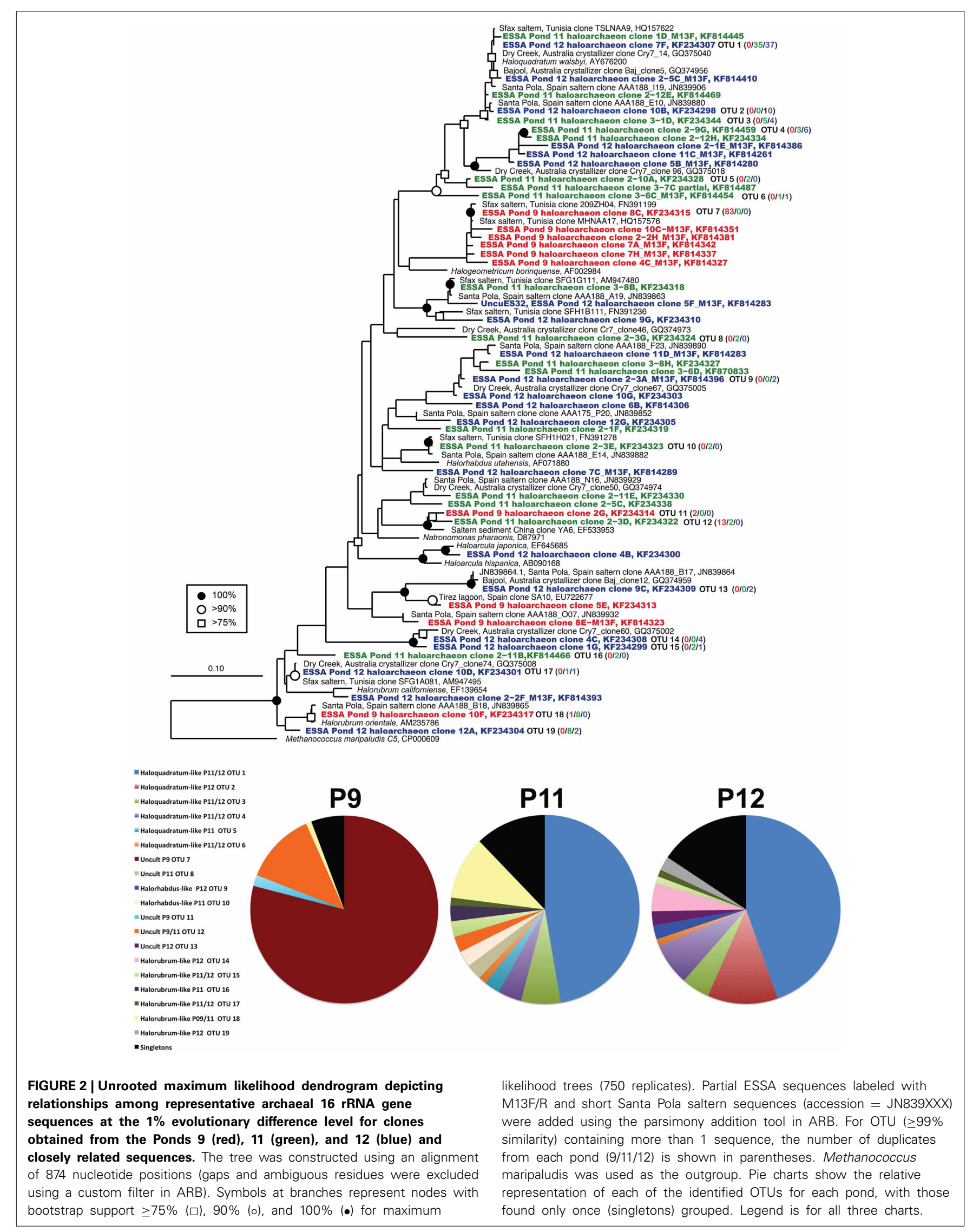


Table 2 | 16S rRNA and bop nucleotide diversity analyses among ESSA source ponds.

\begin{tabular}{|c|c|c|c|c|c|c|c|c|}
\hline Sequence & Source pond & Sequences $(n)$ & OTU & Coverage (\%) & $H$ & $1 / D$ & Ace richness & Chao richness \\
\hline & 11 & 74 & $37,21,17$ & $50,72,77$ & $3.1,2.1,1.8$ & $14.5,4.2,3.1$ & $103,52,26$ & $96,29,20$ \\
\hline \multirow[t]{2}{*}{$B o p(n t)$} & 9 & 66 & $47,11,05$ & $29,84,93$ & $3.7,1.8,1.0$ & $65.0,5.0,2.4$ & $140,33,06$ & $107,14,05$ \\
\hline & 11 & 48 & $31,14,11$ & $35,71,77$ & $3.2,2.2,2.0$ & $31.3,8.2,6.6$ & $134,28,24$ & $64,19,21$ \\
\hline \multirow[t]{3}{*}{ Bacterial $16 \mathrm{~S}$ rRNA } & 9 & 81 & $39,18,16$ & $52,78,80$ & $3.2,2.2,2.0$ & $17.5,6.3,5.5$ & $222,50,43$ & $141,30,25$ \\
\hline & 11 & 69 & $17,07,07$ & $75,90,90$ & $1.8,1.1,1.1$ & $3.4,2 \cdot 0,2 \cdot 0$ & $45,07,07$ & $32,07,07$ \\
\hline & 12 & 77 & $47,31,24$ & $39,60,69$ & $3.6,3 \cdot 0,2.5$ & $39.6,16.6,9.1$ & $386,184,370$ & $399,108,69$ \\
\hline
\end{tabular}

$H$, Shannon-Weaver Diversity Index; $D$, Simpson's diversity index; shown as $1 / D=$ Dominance.

${ }^{1}$ Commas separate mean estimates calculated using 0,1, and 3\% OTU dissimilarity cut-offs respectively for all analyses.

from the ESSA ponds. This included members of the Alpha-, Delta-, and Gammaproteobacteria, Bacteroidetes, Firmicutes, Verrucomicrobia, and algal plastid sequences (Figure 5). Pond 9 communities had relatively high representation of Verrucomicrobial Puniceicoccus-like sequences (OTU 10-11, $22 \%$ of clone), but the largest proportion (47\%) was found in two Gammaproteobacterial phylogroups (Figure 5). The first of these (OTU 12, 14\% of community) was 97\% similar to Spiribacter salinus, a recently isolated photoheterotroph that was found to be abundant ( $\sim 16 \%$ of community) at $\sim 19 \%$ salinity in the Santa Pola saltern in Spain (Ghai et al., 2011; Leon et al., 2013). The second (33\% of community) was $99 \%$ similar to an environmental clone from the Salton Sea, a modestly hypersaline $\left(\sim 40 \mathrm{~g} \mathrm{l}^{-1}\right)$ lake in southern California.

Pond 11 diversity was quite limited, not only in diversity metrics, but also taxonomically since only members of the Phylum Bacteroidetes were detected, including relatives of Psychroflexus, Sediminibacterium, Owenweeksia, and Salinibacter (Figure 5). Psychroflexus-like $(\sim 90 \%$ similarity to cultured species) sequences comprised $\sim 16 \%$ of the Pond 11 library, Sediminibacterium-like species (94\% similarity to S. salmoneum) made up over $7 \%$ of the community. Only three sequences (2 from Pond 11, 1 from Pond 12) were closely related (99\% similar) to a Salinibacter culture isolated from ESSA (Sabet et al., 2009), which is $>98 \%$ similar to the type species S. ruber. However, $69 \%$ of the Pond 11 library was comprised of a single uncultured Bacteroidetes lineage (OTU 5, $<80 \%$ similar to nearest cultured representative Saprospira grandis). This lineage was closely related (>98\% similar) to environmental clones recovered from Lake Tuz in Turkey and a saltern in Chula Vista, CA (Zhaxybayeva et al., 2013). This OTU also made up $\sim 14 \%$ of the community in Pond 12. Despite overlap in this phylogroup, Pond 12 differed from Pond 11 in having a greater number of Deltaproteobacterial sequences ( $40 \%$ of community). This included one abundant group ( $13 \%$ of community) that was $<85 \%$ similar to cultured sulfate-reducing species such as Desulfobacca acetoxidans, but was 96-99\% similar to metagenomic sequences recently obtained in Lake Tyrell in Australia (Podell et al., 2013). Chlorophyte plastid sequences comprised $10 \%$ of the Pond 12 community.
This included one sequence related to the halophilic green alga, Dunaliella ( $~ 97 \%$ similar), but most were only distantly related to cultured algae ( $<80 \%$ similar to Monomastix sequences). Nearly one third of sequences in Pond 12 were singletons, found only once in the library.

The low number of phylotypes in Pond 11 was reflected in low richness and diversity estimates (Table 2) and a nearly flat rarefaction curves for the Pond 11 community (Figure 3C). By contrast, the diversity and richness values in Ponds 9 and 12 were much higher. In Pond 9, there was less OTU redundancy for bacteria than the archaeal community. Somewhat surprisingly, at all OTU levels, richness and diversity metrics were highest in Pond 12 compared to the other ponds, exceeding Shannon index values of 3.0 at the $0 \%$ evolutionary distance. In contrast to the archaeal 16S rRNA results, there was almost no overlap among bacterial sequences obtained from the three ponds with only 2 shared OTUs (OTU 1,5) between communities (Figure 3F). This was confirmed by pairwise $\int$-LIBSHUFF and AMOVA comparisons that revealed highly significant differences between all ponds including 11 and 12 (Table 3).

\section{DISCUSSION}

\section{ARCHAEAL DIVERSITY}

Archaeal 16S rRNA sequence diversity estimates in Ponds 11 and 12 were comparable to those reported for the Santa Pola saltern and somewhat lower than in the Sfax ponds (Baati et al., 2008). The increase in archaeal diversity metrics at higher salinities was driven primarily by increased representation of culturable haloarchaeal groups including Halorubrum and Haloarcula, groups that have been previously isolated from the ESSA saltern (Sabet et al., 2009). Over $60 \%$ of sequences recovered in these two ponds were Haloquadratum-like. Among these, the most abundant lineage recovered from Ponds 11 and 12 (>40\% in each) was only $1 \%$ divergent from the type species Haloquadratum walsbyi. We also identified sequences with lower similarity (93-97\%) to H. walsbyi, that clustered in the phylogeny with a clone recovered in a more recent study in Australian crystallizers (Oh et al., 2010). We suggest that these are likely members of another species of Haloquadratum that has yet to be cultivated. Variation among 


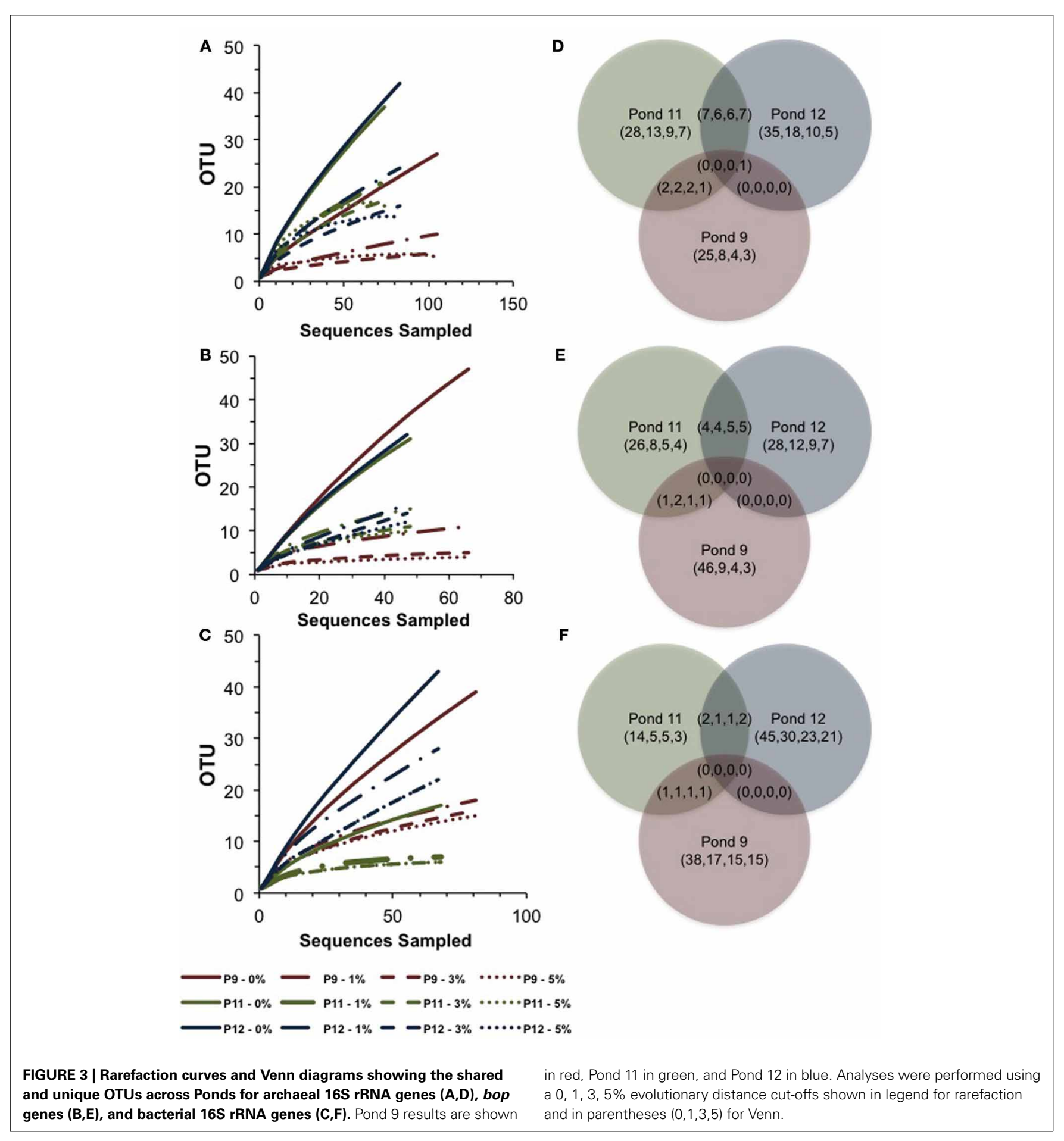

Haloquadratum-like genotypes assayed by DGGE in different ponds in the Sfax saltern has also been reported (Boujelben et al., 2012). It has been speculated that the seemingly cosmopolitan occurrence of Haloquadratum in the highest salinity ponds in salterns may be due to their tolerance of extreme salinity fluctuations and dispersal mechanisms (Oh et al., 2010), although at this point little data is available especially regarding dispersal.
The haloarchaeal community was much less diverse in Pond 9, the main site of gypsum precipitation $\left(\mathrm{CaSO}_{4}\right)$ in the ESSA saltern. The Pond 9 archaeal library was dominated by uncultured lineages, especially a single phylotype $>99 \%$ identical to an environmental sequence recovered from the Sfax multipond saltern in Tunisia (Baati et al., 2010). Interestingly, the phylotype from that study was also recovered from a pond with similar salinity $(\sim 18 \%)$, suggesting this group may be selected by this salinity or 
Table 3 | Community comparisons among ponds for 16S rRNA sequence libraries.

\begin{tabular}{|c|c|c|c|}
\hline Library & Statistic & Comparison & $P$-value \\
\hline \multirow[t]{6}{*}{ Archaea } & AMOVA $^{a}$ & 9 vs. 11 & $<0.001$ \\
\hline & & 9 vs. 12 & $<0.001$ \\
\hline & & 11 vs. 12 & 0.22 \\
\hline & $\int$-Libshuffb & 9 vs. 11 & $<0.001(X Y),<0.001(Y X)$ \\
\hline & & 9 vs. 12 & $<0.001(X Y),<0.001(Y X)$ \\
\hline & & 11 vs. 12 & $0.0002(X Y), 0.1776(Y X)$ \\
\hline \multirow[t]{6}{*}{ Bacteria } & AMOVA & 9 vs. 11 & $<0.001$ \\
\hline & & 9 vs. 12 & $<0.001$ \\
\hline & & 11 vs. 12 & $<0.001$ \\
\hline & $\int$-Libshuff & 9 vs. 11 & $<0.001(\mathrm{XY}),<0.001(\mathrm{YX})$ \\
\hline & & 9 vs. 12 & $<0.001(X Y),<0.001(Y X)$ \\
\hline & & 11 vs. 12 & $<0.001(X Y),<0.001(Y X)$ \\
\hline
\end{tabular}

${ }^{a}$ For AMOVA analyses, $P<0.017$ was considered significant based on Bonferroni corrections for multiple comparisons (significant comparisons bolded).

${ }^{b}$ For Libshuff analyses, pairwise comparisons were made in both directions, so $P<0.0085$ in both directions was considered significant (in bold) based on the Bonferroni correction (Singleton et al., 2001).

some other physicochemical factors across these geographically isolated coastal salterns.

\section{Bop GENE DIVERSITY}

Our findings from archaeal ribosomal gene sequences were largely confirmed in our analyses of the functional gene (bop) coding for bacteriorhodopsins. Overall, we found a diverse assemblage of sequences that clustered within the Halobacterales with comparable rhodopsin gene diversity $\left(\mathrm{H}^{\prime}=1.0-2.2\right.$ at the 1 and $3 \%$ OTU level) compared with past studies of bop gene diversity $\left(\mathrm{H}^{\prime}=\sim 1.4\right.$ ) (Papke et al., 2003; Pašić et al., 2005). There was greater overlap in the sequences recovered in ESSA with those from the Santa Pola saltern (Papke et al., 2003) than the Seèovlje saltern, which was not found to have Haloquadratumlike sequences (Pašić et al., 2005). However, in contrast with Papke et al. (2003), we found more evidence of potential pond-specific communities (i.e., bop phylotypes only found in one of the three ponds). A single bop gene lineage was found to have similarity with a database sequence from a saltern in Chiku, Taiwan (Lin et al., unpublished). No overlap was observed with bacteriorhodopsin sequences recently reported from the Dead sea, an athalassohaline habitat (Bodaker et al., 2012).

Many of the sequences we recovered, especially in Pond 9, were from uncultured lineages, neither closely related to any in the NCBI database, nor closely related to bop sequences from cultures recovered in the ESSA saltern. The sequence novelty may be due in part to unique ESSA-specific phylotypes, but is also likely due to global undersampling and the relative paucity of available environmental bop gene sequence data in databases.

Since this is one of the only studies with directly parallel $16 \mathrm{~S}$ rRNA and bop gene sequencing from the environment, we can attempt to overcome some of the limitations of the limited database for identification. For example, in the archaeal 16S rRNA library in Pond 9, a single phylotype was highly abundant (79\% of library) and exclusively found in this pond. In our bop gene library, an abundant cluster of closely related OTUs $(44 \%$ of library) was also exclusively found in Pond 9. These sequences may all represent variants of bacteriorhodopsin within the same species, as functional genes typically display more genetic variation than highly conserved $16 \mathrm{~S}$ rRNA gene.

\section{BACTERIAL DIVERSITY}

Among our ESSA Pond 9 bacterial sequences, the largest group recovered was $99 \%$ similar to an uncultured gammaproteobacterial sequence from the Salton Sea, a moderately saline $(\sim 40 \mathrm{~g}$ $1^{-1}$ ) endorheic lake in southern California (Dillon et al., 2009a). This suggests that this lineage may live within the lower range of hypersaline conditions and may explain why it was not recovered in Ponds 11 and 12. Interestingly, a number of bacterial sequences from Pond 9 were closely related ( $~ 95 \%$ similar) to sequences recovered in a previous study of the photosynthetic microbial mats found in Pond 4 of the ESSA saltern (Ley et al., 2006) as well as evaporitic mats from Eilat, Israel ( $>99 \%$ similarity) (Sørensen et al., 2005). This suggests that in interconnected saltern systems, the microbial mats found at lower salinities may serve as a source of bacteria resident in the plankton further up the salinity gradient, although recovery of genes via PCR-based methods does not confirm that they were actively growing at these higher salinities.

Algal plastid sequences were obtained in Pond 12. We recovered a single clone of the halophilic alga Dunaliella, which was somewhat unexpected since a past report noted the absence of this group from the ESSA ponds despite its prevalence in other more nutrient-rich salterns (Javor, 1983). However, the most abundant group of plastids sequences (10\% of clones in Pond 12) showed only modest ( $94 \%)$ similarity with an environmental clone found in Lake Tebenquiche in Chile (Demergasso et al., $2008)$, and among cultured relatives was distantly related $(<80 \%$ similar) to the freshwater Prymnesiophyte Monomastix (Turmel et al., 2009), suggesting this may represent a previously unknown halophilic algal lineage.

In contrast to the other two ponds, which had relatively high numbers of taxonomic groups, only members of the Phylum Bacteroidetes were recovered in Pond 11. We found high clonal abundance ( $\sim 27 \%$ of community) of sequences related to Psychroflexus, Owenweeksia, and Sediminibacterium. Psychroflexus strains have been previously cultured from hypersaline habitats (Donachie et al., 2004; Zhang et al., 2010) and members of this genus have been observed in salterns and high altitude athalassohaline lakes in Tibet and Chile (Benlloch et al., 2002; Wu et al., 2006; Dorador et al., 2009). No known halophilic members have been cultured from the Owenweeksia and Sediminibacterium genera, although members of these lineages have been isolated from marine habitats (Lau et al., 2005; Khan et al., 2007). These findings contrast with past studies of hypersaline lakes and salterns where members of the Salinibacter genus were abundant (Anton et al., 2000; Benlloch et al., 2002; Demergasso et al., 2004; Baati et al., 2008). We only rarely detected Salinibacter-like lineages in ESSA, with two clones from Pond 11 closely related (>99\% similar) to a cultured ESSA Salinibacter (Sabet et al., 2009) and one 


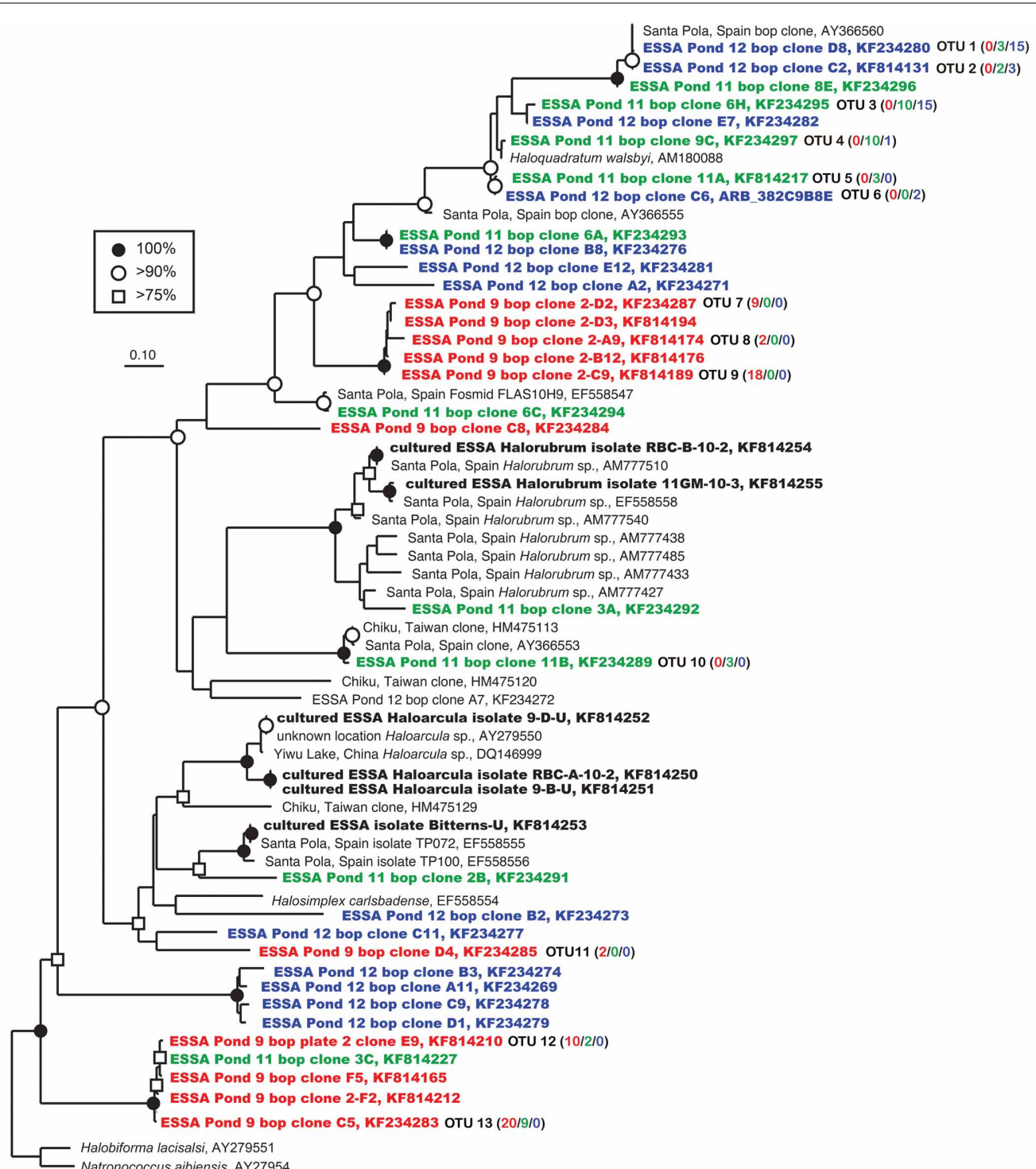

P9

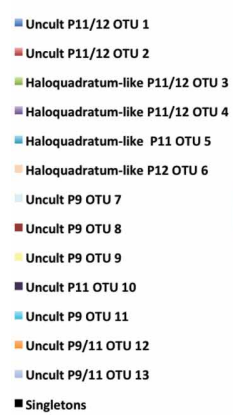

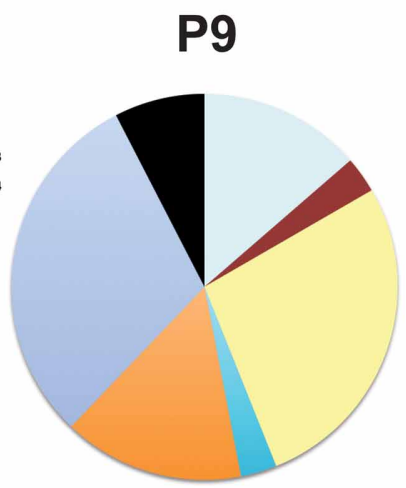

FIGURE 4 | Unrooted maximum likelihood dendrogram depicting relationships among representative bop gene sequences at the $1 \%$ evolutionary difference level for clones obtained from the Ponds 9 (red), 11 (green), and 12 (blue), ESSA cultures (bold) and closely related sequences. The tree was constructed using an alignment of 312 nucleotide positions (gaps and ambiguous residues were excluded using a custom filter in ARB). Symbols at branches represent nodes with bootstrap support $\geq 75 \%$
P11

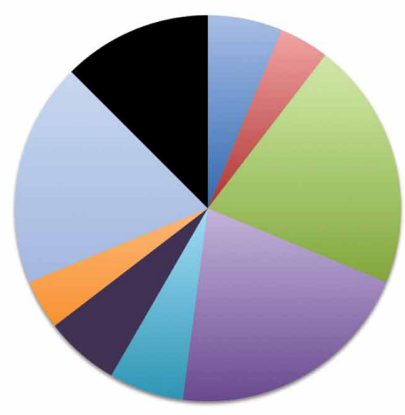

P12

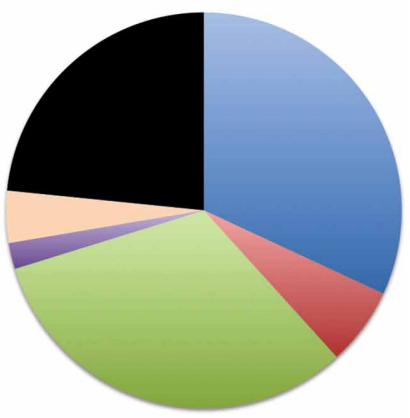

(口), $90 \%$ (०), and 100\% (•) for maximum likelihood trees (550 replicates). For OTU ( $\geq 99 \%$ similarity) containing more than 1 sequence, the number of duplicates from each pond $(9 / 11 / 12)$ is shown in parentheses. Halobiforma lacisalsi and Natronococcus aibiensis sequences were used as outgroups. Pie charts show the relative representation of each of the identified OTUs for each pond, with those found only once (singletons) grouped. Legend is for all three charts. 


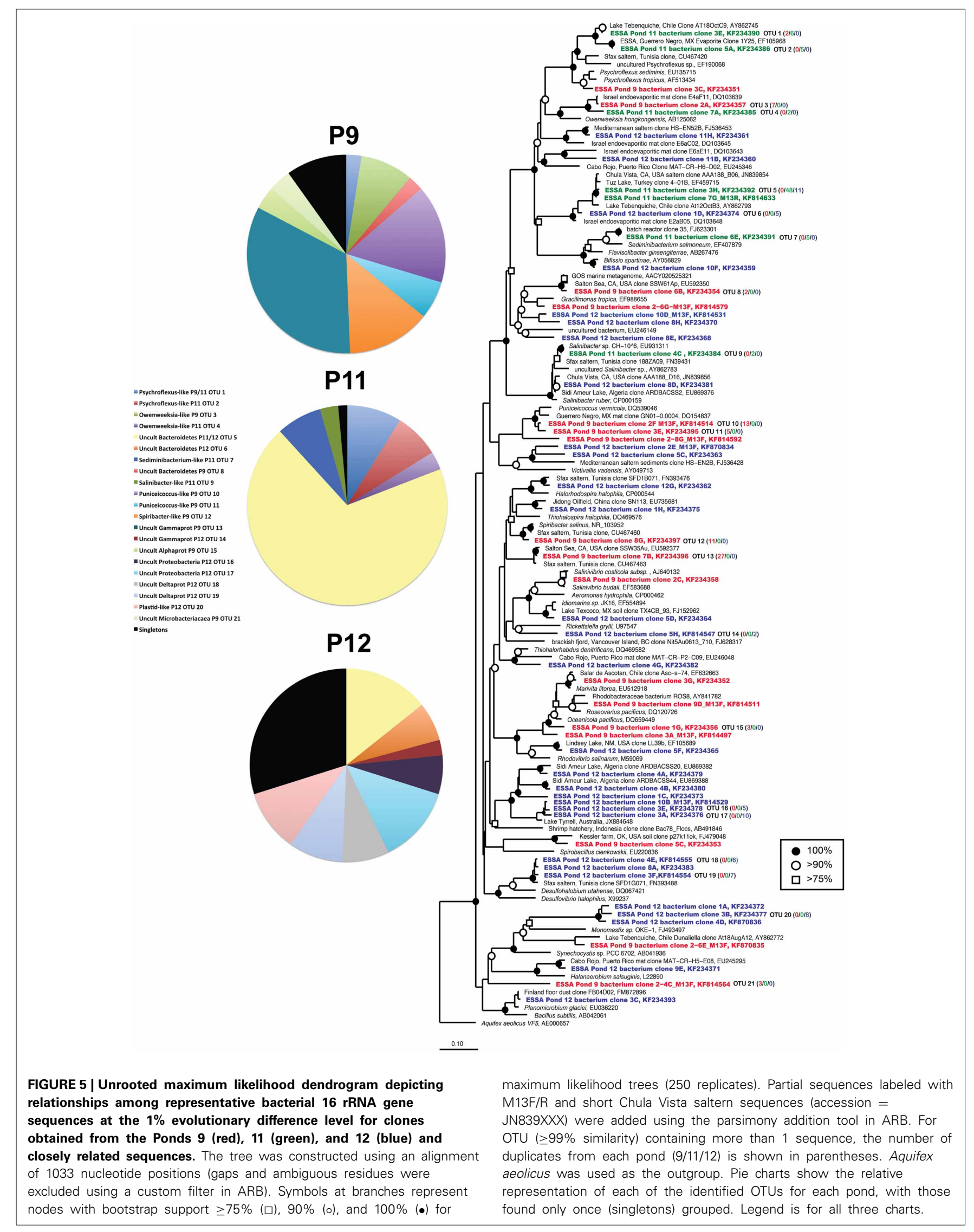


clone $98 \%$ similar to an environmental clone from the saltern in Chula Vista, CA, USA (Zhaxybayeva et al., 2013).

Additionally, an uncultured Bacteroidetes lineage $>98 \%$ similar to clones from Lake Tuz in Turkey (Mutlu et al., 2008) and the Chula Vista, CA, USA saltern (Zhaxybayeva et al., 2013) comprised 69 and $14 \%$ of all bacterial 16 S rRNA clones recovered from Ponds 11 and 12, respectively. This group was also the most commonly identified (29/58 bacteria) using single cell genomics approaches from high salinity ponds $\left(320-350 \mathrm{~g} \mathrm{l}^{-1}\right)$ in the Chula Vista saltern, which is near the US-Mexico border. Both the Chula Vista and ESSA salterns are derived from evaporation of pacific coastal waters and are less than 500 miles apart. The Zhaxybayeva et al. (2013) study found little overlap in bacterial communities between the Chula Vista saltern and the Santa Pola saltern in Spain, suggesting geographic or other unidentified environmental differences may be responsible. The abundance of this Bacteroidetes phylotype in Pond 11 of ESSA and Chula Vista at high salinity suggests there may be environmental factors in common or dispersal mechanisms between the two salterns that explains this. However, not all groups showed the same pattern. Gammaproteobacteria from commonly cultivated genera such as Salicola and Halomonas sequences were abundant in the Chula Vista saltern. Members of these bacterial genera were not detected in this study, despite being isolated from Ponds 9 and 11 in a cultivation study performed using samples collected in parallel to this one (Sabet et al., 2009). The difference in abundance of these culturable groups between the ESSA and Chula Vista salterns may be due to differences in nutrient levels as the latter saltern has been reported to be eutrophic (Javor, 1989). Elevated nutrients in the Chula Vista ponds may more closely resemble culture conditions that favor those lineages.

The novel bacterial community members in Pond 12 were primarily Deltaproteobacteria. Deltaproteobacteria, especially sulfate-reducing lineages, have been commonly identified in saltern sediments (Baati et al., 2010; Lopez-Lopez et al., 2010) and benthic mats (Caumette et al., 1994; Fourçans et al., 2004; Dillon et al., 2009b), but less commonly reported in saltern waters. We would not expect the lineages we recovered in these well-mixed, aerobic ponds to be sulfate reducers. One abundant cluster (17\% of community) was not closely related to cultured members of this subphylum $(<15 \%$ similar to cultured Deltaproteobacterial species), but was 96-99\% similar to metagenomic sequences recently obtained in Lake Tyrell in Australia (Podell et al., 2013) suggesting it may be globally distributed. Overall, these findings combined with other recent studies (Jiang et al., 2007; Pagaling et al., 2009; Baati et al., 2010) indicate that Salinibacter may not always be the most abundant bacterial type in saturated brines and that other Bacteroidetes as well as Proteobacteria may be similarly well-adapted to such extreme salinities and should be targeted for cultivation and further study.

\section{DIVERSITY ALONG THE SALINITY GRADIENT}

Our findings seemed to follow our hypothesized pattern of increasing archaeal and declining bacterial diversity along the salinity gradient from Ponds 9 and 11, but the increase in bacterial diversity, even higher than archaeal diversity, in Pond 12 runs counter to this. This was surprising, since most studies in salterns have found that bacterial diversity declines with increasing salinity. For example, studies comparing the relative abundance of bacterial and archaeal 16S rRNA clones in the Santa Pola and Sfax multipond salterns found very low bacterial diversity (i.e., $\mathrm{H}^{\prime}<1.0$ ) above $300 \mathrm{~g} \mathrm{l}^{-1}$ salinity (Benlloch et al., 2002; Casamayor et al., 2002; Baati et al., 2008). Bacterial phylotypes have been found to outnumber archaea in an athalassohaline lake in the Atacama desert (Demergasso et al., 2004) and an alkaline, hypersaline depression in the Sahara (Mesbah et al., 2007), but the dramatic differences in bacterial populations we observed between Ponds 11 and 12 were unexpected given the similar chemical nature of these two ponds. The only obvious difference between the two sites was the higher degree of precipitation of halite in Pond 12, although this does not rule out some unmeasured physicochemical difference between the two ponds.

Of course, it must be noted that what we were measuring in this study (like the majority of similar studies) is the relative abundance of phylotypes recovered using PCR on a limited sample set, not direct environmental abundances. We used different primer sets for the bacterial and archaeal clone libraries and did not use quantitative PCR, so we cannot directly compare the clonal abundance of bacteria and archaea in these ponds and we cannot assume that the relative clonal abundance represents the actual abundance of cells in the ponds. These patterns are intriguing, but must be confirmed with more quantitative methods (e.g., FISH).

What is clear is that even though the evaporation ponds in the ESSA multipond salterns are interconnected, with evaporating seawater being pumped between the ponds, there are unique, diverse communities of both bacteria and archaea, including diverse bacteriorhodopsin-containing lineages, found in each. Future studies using metagenomic approaches to connect functional genes with taxonomic genes and targeted cultivation of abundant lineages identified in this study are warranted.

\section{ACKNOWLEDGMENTS}

Funding for this project was provided by NIH Minority Bridges Summer Program grant (5R25GM50089-12) and a CSULB SCAC mini-grant to Jesse G. Dillon. We thank Dr. David DesMarais and the NASA AMES EMERG group for logistical support and Dr. Shereen Sabet, Emmerleen Basiana, and Carlos Martinez for their assistance. We thank Dr. R. Thane Papke and the organizing committee for organizing the Halophiles 2013 conferences in Storrs, CT, USA and the two peer-reviewers for helpful suggestions for improving the manuscript.

\section{REFERENCES}

Anton, J., Llobet-Brossa, E., Rodriguez-Valera, F., and Amann, R. (1999) Fluorescence in situ hybridization analysis of the prokaryotic community inhabiting crystallizer ponds. Environ. Microbiol. 1, 517-523. doi: 10.1046/j.14622920.1999.00065.x

Anton, J., Pena, A., Santos, F., Martinez-Garcia, M., Schmitt-Kopplin, P., and Rossello-Mora, R. (2008). Distribution, abundance and diversity of the extremely halophilic bacterium Salinibacter ruber. Saline Syst. 4, 15. doi: 10.1186/1746-1448-4-15

Anton, J., Rossello-Mora, R., Rodriguez-Valera, F., and Amann, R. (2000). Extremely halophilic bacteria in crystallizer ponds from solar salterns. Appl. Environ. Microbiol. 66, 3052-3057. doi: 10.1128/AEM.66.7.3052-3057.2000

Ashelford, K. E., Chuzhanova, N. A., Fry, J. C., Jones, A. J., and Weightman, A. J. (2005). At Least 1 in 20 16S rRNA sequence records currently held in public repositories is estimated to contain substantial anomalies. 
Appl. Environ. Microbiol. 71, 7724-7736. doi: 10.1128/AEM.71.12.7724-773 6.2005

Ashelford, K. E., Chuzhanova, N. A., Fry, J. C., Jones, A. J., and Weightman, A. J. (2006). New screening software shows that most recent large 16S rRNA gene clone libraries contain Chimeras. Appl. Environ. Microbiol. 72, 5734-5741. doi: 10.1128/AEM.00556-06

Baati, H., Guermazi, S., Amdouni, R., Gharsallah, N., Sghir, A., and Ammar, E. (2008). Prokaryotic diversity of a Tunisian multipond solar saltern. Extremophiles 12, 505-518. doi: 10.1007/s00792-008-0154-x

Baati, H., Guermazi, S., Gharsallah, N., Sghir, A., and Ammar, E. (2010). Novel prokaryotic diversity in sediments of Tunisian multipond solar saltern. Res. Microbiol. 161, 573-582. doi: 10.1016/j.resmic.2010.05.009

Benlloch, S., Acinas, S. G., Anton, J., Lopez-Lopez Luz, S. P., and Rodriguez-Valera, F. (2001). Archaeal biodiversity in crystallizer ponds from a solar saltern: culture versus PCR. Microb. Ecol. 41, 12-19. doi: 10.1007/s002480000069

Benlloch, S., Lopez-Lopez, A., Casamayor, E. O., Øvreås, L., Goddard, V., Daae, F. L., et al. (2002). Prokaryotic genetic diversity throughout the salinity gradient of a coastal solar saltern. Environ. Microbiol. 4, 349-360. doi: 10.1046/j.14622920.2002.00306.x

Bodaker, I., Suzuki, M. T., Oren, A., and Béjà, O. (2012). Dead Sea rhodopsins revisited. Environ. Microbiol. Rep. 4, 617-621. doi: 10.1111/j.1758-2229.2012. 00377.x

Boujelben, I., Gomariz, M., Martinez-Garcia, M., Santos, F., Pena, A., Lopez, C., et al. (2012). Spatial and seasonal prokaryotic community dynamics in ponds of increasing salinity of Sfax solar saltern in Tunisia. Antonie Van Leeuwenhoek 101, 845-857. doi: 10.1007/s10482-012-9701-7

Burns, D. G., Camakaris, H. M., Janssen, P. H., and Dyall-Smith, M. L. (2004). Combined use of cultivation-dependent and cultivation-independent methods indicates that members of most haloarchaeal groups in an Australian crystallizer pond are cultivable. Appl. Environ. Microbiol. 70, 5258-5265. doi: 10.1128/AEM.70.9.5258-5265.2004

Casamayor, E. O., Calderon-Paz, J. I., and Pedros-Alio, C. (2000). 5S rRNA fingerprints of marine bacteria, halophilic archaea and natural prokaryotic assemblages along a salinity gradient. FEMS Microbiol. Ecol. 34, 113-119. doi: 10.1111/j.1574-6941.2000.tb00760.x

Casamayor, E. O., Massana, R., Benlloch, S., Øvreås, L., Diez, B., Goddard, V. J., et al. (2002). Changes in archaeal, bacterial and eukaryal assemblages along a salinity gradient by comparison of genetic fingerprinting methods in a multipond solar saltern. Environ. Microbiol. 4, 338-348. doi: 10.1046/j.14622920.2002.00297.x

Caumette, P., Matheron, R., Raymond, N., and Relexans, J. C. (1994). Microbial mats in the hypersaline ponds of Mediterranean salterns (SalinsDe-Giraud, France). FEMS Microbiol. Ecol. 13, 273-286. doi: 10.1111/j.15746941.1994.tb00074.x

Delong, E. F. (1992). Archaea in coastal marine environments. Proc. Natl. Acad. Sci. U.S.A. 89, 5685-5689. doi: 10.1073/pnas.89.12.5685

Demergasso, C., Casamayor, E. O., Chong, G., Galleguillos, P., Escudero, L., and Pedros-Alio, C. (2004). Distribution of prokaryotic genetic diversity in athalassohaline lakes of the Atacama Desert, Northern Chile. FEMS Microbiol. Ecol. 48, 57-69. doi: 10.1016/j.femsec.2003.12.013

Demergasso, C., Escudero, L., Casamayor, E., Chong, G., Balagué, V., and PedrósAlió, C. (2008). Novelty and spatio-temporal heterogeneity in the bacterial diversity of hypersaline Lake Tebenquiche (Salar de Atacama). Extremophiles 12, 491-504. doi: 10.1007/s00792-008-0153-y

Dillon, J. G., McMath, L. M., and Trout, A. L. (2009a). Seasonal changes in bacterial diversity in the Salton Sea. Hydrobiologia 632, 49-64. doi: 10.1007/s10750-0099827-4

Dillon, J. G., Miller, S., Bebout, B., Hullar, M., Pinel, N., and Stahl, D. A. (2009b). Spatial and temporal variability in a stratified hypersaline microbial mat community. FEMS Microbiol. Ecol. 68, 46-58. doi: 10.1111/j.15746941.2009.00647.x

Donachie, S. P., Bowman, J. P., and Alam, M. (2004). Psychroflexus tropicus sp. nov., an obligately halophilic Cytophaga-Flavobacterium-Bacteroides group bacterium from an Hawaiian hypersaline lake. Int. J. Syst. Evol. Microbiol. 54, 935-940. doi: 10.1099/ijs.0.02733-0

Dorador, C., Meneses, D., Urtuvia, V., Demergasso, C., Vila, I., Witzel, K. P., et al. (2009). Diversity of bacteroidetes in high-altitude saline evaporitic basins in northern chile. J. Geophys. Res. Biogeosci. 114, 11. doi: 10.1029/2008JG0 00837
Feazel, L. M., Spear, J. R., Berger, A. B., Harris, J. K., Frank, D. N., Ley, R. E., et al. (2008). Eucaryotic diversity in a hypersaline microbial mat. Appl. Environ. Microbiol. 74, 329-332. doi: 10.1128/AEM.01448-07

Fourçans, A., De Oteyza, T. G., Wieland, A., Solé, A., Diestra, E., Van Bleijswijk, J., et al. (2004). Characterization of functional bacterial groups in a hypersaline microbial mat community (Salins-de-Giraud, Camargue, France). FEMS Microbiol. Ecol. 51, 55-70. doi: 10.1016/j.femsec.2004.07.012

Ghai, R., Pašić, L., Fernandez, A. B., Martin-Cuadrado, A.-B., Mizuno, C. M., McMahon, K. D., et al. (2011). New abundant microbial groups in aquatic hypersaline environments. Sci. Rep. 1. doi: 10.1038/srep00135. Available online at: http://www.nature.com/srep/2011/111031/srep00135/full/srep00135.html

Gihring, T. M., Green, S. J., and Schadt, C. W. (2012). Massively parallel rRNA gene sequencing exacerbates the potential for biased community diversity comparisons due to variable library sizes. Environ. Microbiol. 14, 285-290. doi: 10.1111/j.1462-2920.2011.02550.x

Good, I. J. (1953). The population frequencies of species and the estimation of population parameters. Biometrika 40, 237-264. doi: 10.1093/biomet/40.3-4.237

Javor, B. J. (1983). Planktonic standing crop and nutrients in a saltern ecosystem. Limnol. Oceanogr. 28, 153-159. doi: 10.4319/lo.1983.28.1.0153

Javor, B. J. (1984). Growth potential of halophilic bacteria isolated from solar salt environments: carbon sources and salt requirements. Appl. Environ. Microbiol. $48,352-360$.

Javor, B. J. (1989). Hypersaline Environments: Microbiology and Biogeochemistry, New York, NY: Springer-Verlag. doi: 10.1007/978-3-642-74370-2

Javor, B. J., and Castenholz, R. W. (1981). Laminated microbial mats, Laguna Guerrero Negro, Mexico. Geomicrobiol. J. 3, 237-273. doi: 10.1080/01490458109377766

Jiang, H., Dong, H., Yu, B., Liu, X., Li, Y., Ji, S., et al. (2007). Microbial response to salinity change in Lake Chaka, a hypersaline lake on Tibetan plateau. Environ. Microbiol. 9, 2603-2621. doi: 10.1111/j.1462-2920.2007.01377.x

Khan, S. T., Nakagawa, Y., and Harayama, S. (2007). Sediminibacter furfurosus gen. nov., sp. nov. and Gilvibacter sediminis gen. nov., sp. nov., novel members of the family Flavobacteriaceae. Int. J. Syst. Evol. Microbiol. 57, 265-269. doi: 10.1099/ijs.0.64628-0

Kunin, V., Raes, J., Harris, J. K., Spear, J. R., Walker, J. J., Ivanova, N., et al. (2008). Millimeter-scale genetic gradients and community-level molecular convergence in a hypersaline microbial mat. Mol. Syst. Biol. 4, 198. doi: 10.1038/msb.2008.35

Larkin, M. A., Blackshields, G., Brown, N. P., Chenna, R., McGettigan, P. A., McWilliam, H., et al. (2007). Clustal W and Clustal X version 2.0. Bioinformatics(Oxford) 23, 2947-2948. doi: 10.1093/bioinformatics/ btm 404

Lau, K. W. K., Ng, C. Y. M., Ren, J., Lau, S. C. L., Qian, P.-Y., Wong, P.-K., et al. (2005). Owenweeksia hongkongensis gen. nov., sp. nov., a novel marine bacterium of the phylum 'Bacteroidetes'. Int. J. Syst. Evol. Microbiol. 55, 1051-1057. doi: 10.1099/ijs.0.63155-0

Leon, M. J., Ghai, R., Fernandez, A. B., Sanchez-Porro, C., Rodriguez-Valera, F., and Ventosa, A. (2013). Draft genome of Spiribacter salinus M19-40, an abundant gammaproteobacterium in aquatic hypersaline environments. Genome Announce. 1:e00179. doi: 10.1128/genomeA.00179-12

Ley, R. E., Harris, J. K., Wilcox, J., Spear, J. R., Miller, S. R., Bebout, B. M., et al. (2006). Unexpected diversity and complexity of the Guerrero Negro hypersaline microbial mat. Appl. Environ. Microbiol. 72, 3685-3695. doi: 10.1128/AEM.72.5.3685-3695.2006

Litchfield, C. D., Irby, A., Kis-Papo, T., and Oren, A. (2001). Comparative metabolic diversity in two solar salterns. Hydrobiologia 466, 73-80. doi: 10.1023/A:1014513317746

Lopez-Lopez, A., Yarza, P., Richter, M., Suarez-Suarez, A., Anton, J., Niemann, H., et al. (2010). Extremely halophilic microbial communities in anaerobic sediments from a solar saltern. Environ. Microbiol. Rep. 2, 258-271. doi: 10.1111/j.1758-2229.2009.00108.x

Ludwig, W., Strunk, O., Westram, R., Richter, L., Meier, H., Kumar, Y., et al. (2004). ARB: a software environment for sequence data. Nucleic Acids Res. 32, 1363-1371. doi: 10.1093/nar/gkh293

Manikandan, M., Kannan, V., and Pašić, L. (2009). Diversity of microorganisms in solar salterns of Tamil Nadu, India. World J. Microbiol. Biotechnol. 25, 1007-1017. doi: 10.1007/s11274-009-9980-y

Maturrano, L., Santos, F., Rossello-Mora, R., and Anton, J. (2006). Microbial diversity in maras salterns, a hypersaline environment in the peruvian andes. Appl. Environ. Microbiol. 72, 3887-3895. doi: 10.1128/AEM.02214-05 
Mesbah, N. M., Abou-El-Ela, S. H., and Wiegel, J. (2007). Novel and unexpected prokaryotic diversity in water and sediments of the alkaline, hypersaline lakes of the Wadi an Natrun, Egypt. Microb. Ecol. 54, 598-617. doi: 10.1007/s00248006-9193-y

Miller, M., Pfeiffer, W., and Schwartz, T. (2010). "Creating the CIPRES science gateway for inference of large phylogenetic trees," in Proceedings of the Gateway Computing Environments Workshop, (New Orleans, LA), 1-8.

Mutlu, M. B., Martinez-Garcia, M., Santos, F., Pena, A., Guven, K., and Anton, J. (2008). Prokaryotic diversity in Tuz Lake, a hypersaline environment in Inland Turkey. FEMS Microbiol. Ecol. 65, 474-483. doi: 10.1111/j.15746941.2008.00510.x

Muyzer, G., Teske, A., Wirsen, C. O., and Jannasch, H. W. (1995). Phylogeneticrelationships of Thiomicrospira species and their identification in deep-sea hydrothermal vent samples by denaturing gradient gel-electrophoresis of $16 \mathrm{~S}$ rDNA fragments. Arch. Microbiol. 164, 165-172. doi: 10.1007/BF02529967

Nübel, U., Bateson, M. M., Madigan, M. T., Kuhl, M., and Ward, D. M. (2001). Diversity and distribution in hypersaline microbial mats of bacteria related to Chloroflexus spp. Appl. Environ. Microbiol. 67, 4365-4371. doi: 10.1128/AEM.67.9.4365-4371.2001

Oh, D., Porter, K., Russ, B., Burns, D., and Dyall-Smith, M. (2010). Diversity of Haloquadratum and other haloarchaea in three, geographically distant, Australian saltern crystallizer ponds. Extremophiles 14, 161-169. doi: 10.1007/s00792-009-0295-6

Oren, A. (2002). Molecular ecology of extremely halophilic Archaea and Bacteria. FEMS Microbiol. Ecol. 39, 1-7. doi: 10.1111/j.1574-6941.2002.tb00900.x

Oren, A. (2008). Microbial life at high salt concentrations: phylogenetic and metabolic diversity. Saline Syst. 4, 2. doi: 10.1186/1746-1448-4-2

Oren, A., and Rodriguez-Valera, F. (2001). The contribution of halophilic Bacteria to the red coloration of saltern crystallizer ponds. FEMS Microbiol. Ecol. 36, 123-130. doi: 10.1111/j.1574-6941.2001.tb00832.x

Øvreås, L., Daae, F. L., Torsvik, V., and Rodriguez-Valera, F. (2003). Characterization of microbial diversity in hypersaline environments by melting profiles and reassociation kinetics in combination with terminal restriction fragment length polymorphism (T-RFLP). Microb. Ecol. 46, 291-301. doi: 10.1007/s00248-003-3006-3

Pagaling, E., Wang, H., Venables, M., Wallace, A., Grant, W. D., Cowan, D. A., et al. (2009). Microbial biogeography of six salt lakes in Inner Mongolia, China, and a salt lake in Argentina. Appl. Environ. Microbiol. 75, 5750-5760. doi: 10.1128/AEM.00040-09

Papke, R. T., Douady, C. J., Doolittle, W. F., and Rodríguez-Valera, F. (2003). Diversity of bacteriorhodopsins in different hypersaline waters from a single Spanish saltern. Environ. Microbiol. 5, 1039-1045. doi: 10.1046/j.14622920.2003.00501.x

Papke, R. T., Zhaxybayeva, O., Feil, E. J., Sommerfeld, K., Muise, D., and Doolittle, W. F. (2007). Searching for species in haloarchaea. Proc. Natl. Acad. Sci. U.S.A. 104, 14092-14097. doi: 10.1073/pnas.0706358104

Pašić, L., Bartual, S. G., Ulrih, N. P., Grabnar, M., and Velikonja, B. H. (2005). Diversity of halophilic archaea in the crystallizers of an Adriatic solar saltern. FEMS Microbiol. Ecol. 54, 491-498. doi: 10.1016/j.femsec.2005.06.004

Podell, S., Ugalde, J. A., Narasingarao, P., Banfield, J. F., Heidelberg, K. B., and Allen, E. E. (2013). Assembly-driven community genomics of a hypersaline microbial ecosystem. PLoS ONE 8:e61692. doi: 10.1371/journal.pone.0061692

Pruesse, E., Quast, C., Knittel, K., Fuchs, B. M., Ludwig, W., Peplies, J., et al. (2007). SILVA: a comprehensive online resource for quality checked and aligned ribosomal RNA sequence data compatible with ARB. Nucleic Acids Res. 35, 7188-7196. doi: $10.1093 / \mathrm{nar} / \mathrm{gkm} 864$

Robertson, C. E., Spear, J. R., Harris, J. K., and Pace, N. R. (2009). Diversity and stratification of archaea in a hypersaline microbial mat. Appl. Environ. Microbiol. 75, 1801-1810. doi: 10.1128/AEM.01811-08

Sabet, S., Diallo, L., Hays, L., Jung, W., and Dillon, J. (2009). Characterization of halophiles isolated from solar salterns in Baja California, Mexico. Extremophiles 13, 643-656. doi: 10.1007/s00792-009-0247-1
Sahl, J. W., Pace, N. R., and Spear, J. R. (2008). Comparative molecular analysis of endoevaporitic microbial communities. Appl. Environ. Microbiol. 74, 6444-6446. doi: 10.1128/AEM.00879-08

Schloss, P. D. (2008). Evaluating different approaches that test whether microbial communities have the same structure. ISME J. 2, 265-275. doi: 10.1038/ismej.2008.5

Schloss, P. D., Westcott, S. L., Ryabin, T., Hall, J. R., Hartmann, M., Hollister, E. B., et al. (2009). Introducing Mothur: open-source, platform-independent, community-supported software for describing and comparing microbial communities. Appl. Environ. Microbiol. 75, 7537-7541. doi: 10.1128/AEM.01541-09

Singleton, D. R., Furlong, M. A., Rathbun, S. L., and Whitman, W. B. (2001). Quantitative comparisons of $16 \mathrm{~S}$ rRNA gene sequence libraries from environmental samples. Appl. Environ. Microbiol. 67, 4374-4376. doi: 10.1128/AEM.67. 9.4374-4376.2001

Sørensen, K. B., Canfield, D. E., Teske, A. P., and Oren, A. (2005). Community composition of a hypersaline endoevaporitic microbial mat. Appl. Environ. Microbiol. 71, 7352-7365. doi: 10.1128/AEM.71.11.7352-7365.2005

Stahl, D. A., Flesher, B., Mansfield, H. R., and Montgomery, L. (1988). Use of phylogenetically based hybridization probes for studies of ruminal microbial ecology. Appl. Environ. Microbiol. 54, 1079-1084.

Trigui, H., Masmoudi, S., Brochier-Armanet, C., Barani, A., Grégori, G., Denis, M., et al. (2011). Characterization of heterotrophic prokaryote subgroups in the Sfax coastal solar salterns by combining flow cytometry cell sorting and phylogenetic analysis. Extremophiles 15, 347-358. doi: 10.1007/s00792-0110364-5

Turmel, M., Gagnon, M. C., O'Kelly, C. J., Otis, C., and Lemieux, C. (2009). The chloroplast genomes of the green algae Pyramimonas, Monomastix, and Pycnococcus shed new light on the evolutionary history of prasinophytes and the origin of the secondary chloroplasts of euglenids. Mol. Biol. Evol. 26, 631-648. doi: $10.1093 / \mathrm{molbev} / \mathrm{msn} 285$

Wu, Q. L., Zwart, G., Schauer, M., Kamst-Van Agterveld, M. P., and Hahn, M. W. (2006). Bacterioplankton community composition along a salinity gradient of sixteen high-mountain lakes located on the Tibetan Plateau, China. Appl. Environ. Microbiol. 72, 5478-5485. doi: 10.1128/AEM.00767-06

Youssef, N. H., and Elshahed, M. S. (2008). Species richness in soil bacterial communities: a proposed approach to overcome sample size bias. J. Microbiol. Methods 75, 86-91. doi: 10.1016/j.mimet.2008.05.009

Zhang, H., Hosoi-Tanabe, S., Nagata, S., Ban, S., and Imura, S. (2010). Psychroflexus lacisalsi sp. nov., a moderate halophilic bacterium isolated from a hypersaline lake (Hunazoko-Ike) in Antarctica. J. Microbiol. 48, 160-164. doi: 10.1007/s12275-010-0018-9

Zhaxybayeva, O., Stepanauskas, R., Mohan, N., and Papke, R. T. (2013). Cell sorting analysis of geographically separated hypersaline environments. Extremophiles 17, 265-275. doi: 10.1007/s00792-013-0514-z

Conflict of Interest Statement: The authors declare that the research was conducted in the absence of any commercial or financial relationships that could be construed as a potential conflict of interest.

Received: 03 July 2013; paper pending published: 31 August 2013; accepted: 04 December 2013; published online: 20 December 2013.

Citation: Dillon JG, Carlin M, Gutierrez A, Nguyen V and McLain N (2013) Patterns of microbial diversity along a salinity gradient in the Guerrero Negro solar saltern, Baja CA Sur, Mexico. Front. Microbiol. 4:399. doi: 10.3389/fmicb.2013.00399

This article was submitted to Extreme Microbiology, a section of the journal Frontiers in Microbiology.

Copyright $\odot 2013$ Dillon, Carlin, Gutierrez, Nguyen and McLain. This is an openaccess article distributed under the terms of the Creative Commons Attribution License (CC BY). The use, distribution or reproduction in other forums is permitted, provided the original author(s) or licensor are credited and that the original publication in this journal is cited, in accordance with accepted academic practice. No use, distribution or reproduction is permitted which does not comply with these terms. 